\title{
The Behavioral Intention of Micro Enterprises to Use the Integrated Cash Waqf Micro Enterprise Investment (ICWME-I) Model as a Source of Financing
}

\author{
Mohamed Asmy Bin Mohd Thas Thaker, Mustafa Omar Mohammed, Jarita Duasa, and \\ Moha Asri Abdullah \\ International Islamic University Malaysia
}

\begin{abstract}
This study is designed to examine the behavioural intention of micro enterprises to use the Integrated Cash Waqf Micro Enterprise Investment (ICWME-I) model as a source of financing in Malaysia. The primary data are collected from the survey administered to micro entrepreneurs in the Klang Valley and the analysis is conducted using Structural Equation Modeling (SEM). Furthermore, the model has validated its acceptance in the field by adopting the Theory of Reasoned Action (TRA). This study has revealed that both the attitude and subjective norms are found to have a positive impact on the intention of micro entrepreneurs to use the ICWME-I Model in the context of Malaysia.

Abstrak: Penelitian ini dirancang untuk menguji niat perilaku usaha mikro menggunakan model investasi usaha mikro wakaf tunai integrasian (ICWME-I) sebagai sumber pembiayaan di Malaysia. Data primer dikumpulkan dari survei yang dibagikan kepada pengusaha mikro di Klang Valley dan analisis dilakukan dengan menggunakan structural equation modeling (SEM). Selanjutnya, model telah divalidasi dengan mengadopsi theory of reasoned action (TRA). Penelitian ini telah menunjukkan bahwa sikap dan norma subjektif memiliki dampak positif pada niat pengusaha mikro untuk menggunakan model ICWME-I di Malaysia.
\end{abstract}

Keywords: cash waqf; micro enterprises; structural equation modeling (SEM); theory of reasoned action

JEL classification: M13, H53, I31

* Corresponding author's e-mail: asmy@iium.edu.my 


\section{Introduction}

Micro Enterprises (MEs) have played an essential role in contributing to economic growth, employment generation and industrialization through entrepreneurship development. The contributions of these MEs to the national economy can be determined in terms of some inter-related issues: economic (income generation), social (poverty reduction) and political (wealth redistribution) (Nasrullah 2012). In terms of their economic contributions, this includes employment creation, wealth creation, the expansion of output, the utilization of local resources and the adaptation of indigenous technologies. Meanwhile, the social benefits include other dimensions such as a reduction of poverty, balanced development, the provision of goods and services appropriate to local needs, a seed bed for new initiatives, and redistribution of both income and opportunity in the community. On the other hand, the role of the MEs in politics can be realized from the redistribution of wealth, opportunities and therefore power within the community (Nasrullah 2012). Furthermore, it is noted that the MEs' contributions also cover a wide range of areas and sectors with a disproportionate number of total establishments in many countries.

Some statistics indicate that they account for more than 70 percent of all regional enterprises and up to 50 percent of paid employment, including in Malaysia. In Malaysia, MEs form the largest composition of enterprises, along with small and medium enterprises with 77 percent, 20 percent and 3 percent respectively (Economic Census: Profile of SMEs 2011). MEs in Malaysia are defined as establishments with less than 5 employees, or less than RM 250,000 in sales turnover for all sectors, namely for agriculture, mining and quarrying, construction, ser- vices and manufacturing. In terms of their contribution to the national gross output and value added, Malaysian MEs contributed RM93.6 billion and RM54.53 billion, respectively (Economic Census: Profile of SMEs 2011). Meanwhile, for the total employment figures by the MEs in Malaysia, they employed 1.3 million workers or 36.5 percent, with an average of 3 workers per establishment.

Despite being recognized for their importance and contribution towards the Malaysian economy, many constraints to the MEs development exist, and the most formidable constraint is the lack of access to external finance. To grow and prosper, businesses of all sizes including the MEs, need access to financial services. However, the studies by Hashim (1999), Ting (2004), Saleh and Ndubisi (2006), Abdullah and Mannan (2010), SME Annual Report (2011/2012), SME Masterplan (2012-2020), and Aris (2006) pointed out that the lack of access to external financing from financial institutions and government agencies were cited as major hindrances to the MEs development. Among the factors that hindered their access to external finance are (i) inadequate collateral, (ii) insufficient legal status, (iii) high transaction costs, (iv) insufficient information and documentation, (v) no financial track record, (vi) the nature and quality of their business, (vii) rigidity in the financing procedures and (viii) a lack of awareness about the financial facilities. Furthermore, most of the financial institutions do not serve MEs, because MEs are perceived as having a high risk of defaulting on loans, and also because of the high costs involved in small transactions and perceived low relative profitability.

In order to address the issue of accessing external financing by the MEs, the Malaysian government has introduced several 
financial assistance programs and allocations over the years to enhance financial accessibility. For example, in 2013, the Government implemented a total of 139 programs with a financial commitment of RM9.9 billion for the SMEs. In addition, the Government is also working together with the private sector in undertaking another 15 programs which amount to RM8.5 billion of funding. Altogether, there are 154 programs amounting to RM18.4 billion. From these allocations, access to financing accounts for 38 percent of the total number of programs and 93 percent (RM9.2 million) of the total funds committed by the Government during the year (SME Annual Report 2012/2013).

Although the government has allocated a huge amount for financial assistance and provided various programs for the SMEs, the effort is seen as being less effective when the impact from the business activities receiving this funding is found to be insignificant (Abdullah et.al, 2001). Such a situation occurs when the assistance program is offered through many government or private agencies without appropriate oversight. According to Abdullah et.al (2001), the ineffectiveness of these assistance programs is due to: (i) the limited number of SMEs which receive the full range of assistance, (ii) inefficient allocation of the resources, and (iii) the programs only focus on developing new enterprises. Therefore, in spite of the Government's efforts to promote financial accessibility through various measures, the micro enterprises are still facing the problem of accessing external financing.

To meet the need for financial services by micro enterprises, alternative approaches have been introduced and applied in many developing countries by utilizing microfinance institutions (Suryana and Komaladewi 2012; Akorsu 2012; Ngehnevu and Nembo 2010;
Husain et al. 2005; Nawaii and Shariff 2011; Mondal 2012; Ventkatasubramanyan 2001) and Islamic microfinance institutions (Muhammad 2012). However, the suggested former model of using microfinance institutions was of no avail in solving those problems, particularly when related to high interest rates (Anyanwu 2004; Parveen 2009; Weiss and Montgomery 2004). Also, Islamic microfinance institutions face their own issues when the existing practices of the Islamic microfinance institutions tend to converge with the conventional practices (Muhammad 2012). For example, the financing modes being used by the Islamic microfinance institutions are mostly debtbased, which has a similarity to the interestbased conventional modes (Muhammad 2012). In some Muslim countries, the Islamic microfinance institutions' operations tend to be costly due to the dominance of Murabahab practices, or administrative charges that are tantamount to riba (Hassan 2010; Muhammad 2012). Furthermore, most of the suggested models focus on the SMEs in general, rather than on the component-based SMEs, particularly the micro enterprises. There is a lack of a well developed and tested model specifically for these micro enterprises.

There is therefore an urgent need for an alternative model that could improve the financial accessibility of the micro enterprises. This paper proposes an Integrated Cash Waqf Micro Enterprise Investment (ICWME-I) model as a viable solution to the problems that micro enterprises in Malaysia continue to face. The proposal could help to improve the situation that is deteriorating almost all the time. Later, we will show this study's use of the Theory of Reasoned Action (TRA) to justify the behavioral intention of micro entrepreneurs to using the ICWME-I model. To the best knowledge of the researcher, there 
has been little research into cash waqf and micro enterprises using TRA. The present research was designed to test empirically the behavioral intention of micro entrepreneurs in using the ICWME-I model.

\section{Literature Review}

\section{Empirical Studies on the Problem of Accessing Finance}

Several empirical studies had indicated that the micro enterprises in Malaysia suffered from the problem of accessing external financing. The lack of collateral, insufficient documents to support a loan application, no financial track record, the nature of the business and a long loan processing time are some of the factors that prevented them from accessing external financing (Aris 2006).

For example, in 2010, Hassan et al. examined the financial constraints faced by the micro enterprise entrepreneurs in Malaysia. Based on their observations, they found that in general, micro entrepreneurs faced financial difficulties particularly during the startup stage. They also found that the rigidity of the procedures to access financial programs hampered the smooth success of the programs. Their general observations were also supported by the studies by Selamat et al. (2011) and Kasim et al. (2010).

Selamat et al. (2011) examined the challenges to the performance of micro enterprises in a particular place in Malaysia, namely Balik Pulau, which is in Penang. By using indepth interviews with 21 respondents, they found that limited access to finance was a significant challenge that affected the micro entrepreneurs in that area. Due to the lack of access to external financing, many of them were using their own savings to start their businesses. These findings were also consistent with Subramaniam (2010), who examined the challenges faced by youths in micro enterprises in Malaysia. Based on her personal interviews with several of them, she pointed out that the lack of access to external financing became a major factor that led them to rely more on internal financing.

These two studies' findings are also relevant to the micro enterprises in other states in Malaysia, such as in Perak, Selangor and Melaka. For instance, Salleh and Sidek in 2011 studied the issues that were faced by the rural micro enterprises in Perak. For this study, they interviewed 30 entrepreneurs involved in rural micro enterprises. Their results revealed that most of the entrepreneurs faced the problem of access to financing. In the state of Selangor, Ali et al. (2010) examined the problems facing by Malay micro entrepreneurs. Based on the feedback received from 65 respondents, the authors revealed that most of the Malay micro entrepreneurs faced similar problem of access to financing. Furthermore, for the case of Melaka, Kasim et al. (2010) examined the challenges that hindered the development of Malay female micro entrepreneurs. Their result also provided similar results, in that most of the female micro entrepreneurs claimed that the lack of access to finance hampered their businesses' development.

Meanwhile, in the current study by Meza (2012), he examined the financial barriers to micro enterprises in Malaysia and Costa Rica. He used in-depth personal interviews with micro entrepreneurs. He found out that access to the financing offered by public banking institutions in Malaysia and Costa Rica were characterized as not being attractive and lacking in adequate collateral to support the micro enterprises' financial and economic needs. Therefore, due to the lack of access 
to the financial sources, most poor and lowincome micro entrepreneurs continued to rely on self-financing or informal sources of financing.

The challenges facing the Malaysian SMEs are apparently shared by SMEs in other countries. For example Stephanou and Rodriguez (2008) examined the financing challenges faced by SMEs in Colombia. Based on the data collected and interviews with the authorities of the SMEs, the lack of access to finance has been cited as an important problem for the SMEs, and was ranked among the most important constraints, particularly for smaller and newer firms. According to the authors, the most important factors limiting access to finance were related primarily to interest rates, the maturity of the businesses, collateral requirements and lending procedures.

Ganbold (2008) found that in Mongolia, access to finance, especially external finance, for SMEs remained a major obstacle. According to his findings, he found that the large firms could gain easy access to finance for their capital requirements, compared to the micro enterprises. The main reasons that hindered them from access to finance were the high interest rates, limited access to long term loans, collateral requirements and a weak capacity to produce a proper business plan.

Meanwhile, in the case of Thailand, Punyasvatsut (2011) found that 40 percent of Thai firms, most of them small, could gain access to credit. The remaining 60 percent faced difficulties in getting access to financing. Based on the feedback received from the SMEs, inadequate collateral, a lack of business experience, the lack of a sound business plan, a non-performing loan history, and high transaction costs prevented them from accessing finance.
Ung and Hay (2011) studied the financial constraints faced by SMEs in Cambodia. Based on their findings using 180 randomly selected firms, they discovered that the firms with high sales volumes and high profit margins easily gained access to financing. Meanwhile, the small businesses were blocked from accessing finance due to the high collateral requirement, restrictions on the size of loans, high interest rates and short repayment periods.

Machmud and Huda (2011) examined the financial constraints faced by Indonesian SMEs. Based on their findings, about 44 percent of their SME respondents relied on internal financial sources, particularly personal savings and retained earnings. The respondents indicated that the two most important reasons for a loan application to be turned down were: (i) a poor credit history and (ii) a poor business plan.

Tadesse (2011) investigated the failure of Micro and Small Enterprises (MSEs) in the sub-city of Addis Ababa Arada, Ethiopia. He used a survey covering 49 randomly selected MSEs to examine whether firms had problems accessing finance or not. Based on his findings, the lack of access to finance was caused by such factors as the inappropriate delivery of the loans, high collateral requirements, high interest rates, the small size of the available loans and the limited availability of financial instruments.

\section{Theory of Reasoned Action}

The Theory of Reasoned Action (TRA) is used to predict an individual's behavioral intention based upon his/her attitude towards the behavioral and subjective norms (Fishbein and Azjen 1975). An individual's positive or negative evaluation of performing the behavior is identified as their attitude towards the 
behavior. Meanwhile, the subjective norm refers to the perception of a person to the social pressure put on him/her to perform, or not to perform, the behavior (Lada et al. 2009).

According to the theory, attitudes are derived from beliefs. Usually, a person will hold a favorable attitude toward performing the behavior if it leads to mostly positive outcomes, while a person who believes that performing the behavior will lead to mainly negative outcomes will hold an unfavorable attitude to it (Lada et al. 2009). The subjective norm is also a function of the beliefs that reflect the influence of individuals or groups to think whether he/she should or should not perform the behavior. These beliefs are termed normative beliefs. A person who believes that most referents with whom he is motivated to comply think he should perform the behavior will receive social pressure to do so (Lada et al. 2009). Figure 1 represents the TRA model in a structural form.

The TRA has received great popularity in many disciplines, due its flexibility and ease of application to different situations (Ramayah et al. 2003). This theory has been applied in different contexts such as in businesses, information technology (IT), health, banking, Islamic banking and many others.

For example, Fauziah et al. (2008) examined the intentions of consumers in Malaysia to engage in a diminishing partnership contract from an Islamic bank for their home financing. By utilizing 300 samples, the result indicated that both the attitude and subjective norms were able to explain the behavioral intention, with the subjective norms giving more influence.

Meanwhile, Abiden et al. (2001) and Sapingi et al. (2011) studied zakat payment behavior among Muslim employees and academics in Malaysia. Based on the feedback received from 231 respondents, they found that the attitude towards the behavior and subjective norm significantly influenced the intention to pay the zakat.

Alternatively, Lada et al. (2009) examined which factors led to a consumer choosing halal products in Labuan, Malaysia. The findings indicated that the TRA was able to predict the intention to choose halal products. The attitude and subjective norms were found to be positively related to the intention, with the subjective norm being the more influential predictor.

Realizing the application of the TRA in various fields, this study aimed for the additional contribution from the TRA in the area of the Islamic voluntary sector, specifically the waqf. To the best knowledge of the researcher, there has been little research into cash waqf and micro enterprises using the TRA. The present research was designed to test empirically the behavioral intention of micro entrepreneurs to using the ICWME-I

Figure 1. Model of Theory of Reasoned Action

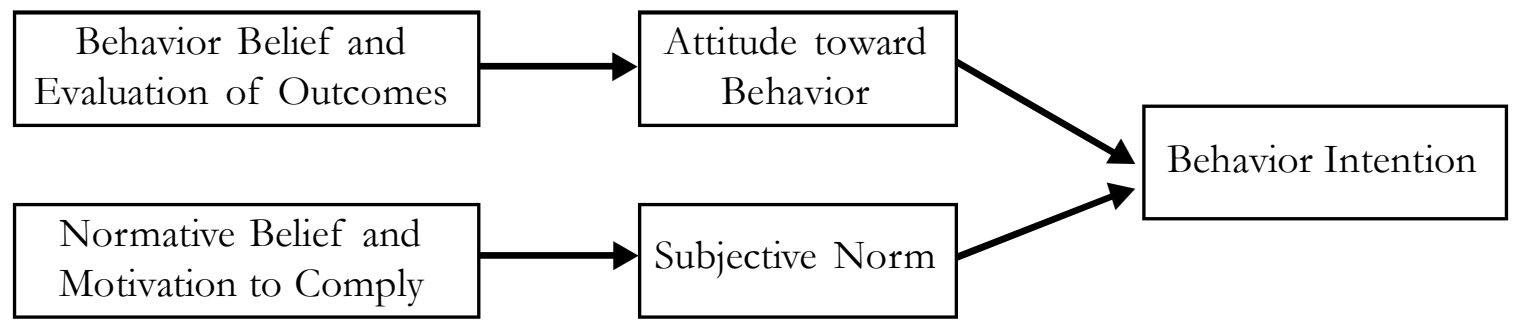


model. Thus the present study is intended to examine the following Research Questions (RQ) after developing the ICWME-I model:

1) To what extent can attitude influence the intention of micro entrepreneurs to use the Integrated Cash Waqf Micro Enterprise Investment (ICWME-I) model?

2) To what extent can the subjective norms influence the intention of micro entrepreneurs to use the Integrated Cash Waqf Micro Enterprise Investment (ICWME-I) model?

\section{Hypotheses Development}

Based on the TRA, the research hypotheses are posited to identify the effect of both attitude and the subjective norm on the behavioral intention of micro enterprises to use the ICWME-I Model. The hypotheses are as follows:

$H_{a}$ 1: The attitude of micro entrepreneurs is significantly (positively) affecting their intention to use the Integrated Cash Waqf Micro Enterprise Investment (ICWME-I) model.

$\mathrm{H}_{a}$ 2: The subjective norm of micro entrepreneurs is significantly (positively) affecting their intention to use the Integrated Cash Waaf Micro Enterprise Investment (ICWME-I) model.

\section{The Need For an Alternative Model}

The problem in accessing external finance by the MEs in Malaysia, as discussed by Hashim, (1999), Hassan et al. (2010), Kasim et al. (2010), Selamat et al. (2011), Salleh and Sidek (2011), Ali et al. (2010) and Meza (2012) is due basically to the following reasons: (i) inadequate collateral, (ii) insufficient legal status, (iii) high transaction costs, (iv) insufficient information and documen- tation, (v) no financial track record, (vi) the nature and quality of their business, (vii) rigidity in the financing procedures and (viii) a lack of awareness about the financial facilities.

Therefore these problems, which will lead to a failure to secure the necessary capital, call for an alternative model that will be based on a collateral-free, profit-risk sharing relationship, which is cost efficient, increase extension services and an interest free system that will increase productivity and value added products. Since the existing programs run by the financial services are not able to produce significant results, it is reasonable to develop and adopt a new model that would restore the position of Malaysia's micro enterprises, so they are again one of the important segments of its economic development.

This paper therefore propose an Integrated Cash Waqf Micro Enterprise Investment (ICWME-I) model which is a participatory form of contract between the Cash Waqf Institution (CWI) and the micro enterprises as an alternative to the existing policies. The ICWME-I model is expected to mitigate or minimize the aforementioned problems. This is due to the fact that no collateral or interest is required, it is free from third party intervention, has enhanced extension services, any profits realized from the investments, and any risks, are shared among the parties and it will facilitate value added products. Under the ICWME-I model, the CWI will be compelled to provide a financial facility and continuously monitor and educate the micro enterprises in order to maximize their revenues and protect the capital invested. Due to the absence of interest and collateral in the ICWME-I model, micro enterprises will have the opportunity and motivation to increase their scale of operations. 


\section{Proposed Model}

\section{Overview of Waqf, Cash Waqf and Its Characteristics}

Waqf literally means to stay in perpetuity (Ahmed 2004). Technically, it is holding a maal (an asset) and repeatedly extracting its usufruct for the benefit of an objective representing righteousness and/or philanthropy for as long as its principal is preserved by its own nature - as in land - or from arrangements and conditions prescribed by the waqf founder (Kahf 2003).

The waqf needs to fulfil three main important characteristics, namely (i) irrevocability (ii) perpetuity, and (iii) inalienability. The donor cannot revoke his donation once the property is declared as waqf, and this is known as irrevocability. The perpetuity of the waqf property occurs where the declaration by the donor is binding and perpetual in nature, hence fixed asset properties. It is known as the perpetuity of the waqf property. This perpetuity brings benefits for both the donor and the beneficiaries. Meanwhile, the waqf property is not subject to sale, disposition, mortgage, gift, inheritance, attachment, or any alienation whatsoever and this is known as the inalienability of the waqf property.

During Islamic history and civilization, waqf has played a significant role in the provision of social benefits, such as education and health, public facilities (roads, bridges and national security), commercial business, utilities (water and sanitation), religious services (the building and maintenance of mosques and graveyards), helping the poor, orphans and the needy, creating employment, supporting the agricultural and industrial sectors, all without imposing any cost on the government (Mohsin 2008).
A cash waqf means the devotion of an amount of money by a founder and the dedication of its usufruct in perpetuity to a prescribed purpose (Mohsin 2008). In this case, the donor endows a cash waqf instead of real estate or a fixed asset. The use of cash waqf came into prominence in the $8^{\text {th }}$ century after Imam Zufar approved their use (Cizakza 2004). Based on his view, a cash waqf can be invested through Mudarabah and the profits generated would be spent for the charity's purposes.

Later, in early $15^{\text {th }}$ century these endowments (cash waqf) had been approved by the Ottoman courts and they had become the dominant form of waqf donations and were extremely popular until the end of the $16^{\text {th }}$ century (Cizakza 2004). During the Ottoman period, education, public works, health and religious services were financed by cash waqf (Toroman et al. 2007). Due to the historical and golden role of cash waqf in the past, nowadays in the 21 st century, there is growing evidence of the revitalization of interest, promotion and rethinking into the role of the cash waqf for community development.

One of the suggestions that arose is to integrate a waqf into enterprises. Several contemporary Muslim scholars have attempted to integrate waqf for small and medium enterprises, particularly to support their financial needs. In the next section, this study will unveil a number of earlier studies that integrated waqf with human capital development.

\section{Waqf and Financing}

A good number of studies stressed the utilization of cash waqf for the financing of enterprises, particularly micro enterprises (Elgari 2004; Cizakca 2004; Dusuki 2008; Hasan 2010). According to these studies, the 
proper utilization of the waqf mechanism, as a source of financing, can play a role in providing sufficient funding for the micro entrepreneurs.

For example, in 2004, Elgari came out with the idea to integrate waqf into the concept of interest free loans or Qard Hassan. The aim was to provide a source of financing for the poor and those restricted from accessing regular financial institutions. In order to perform this operation, Elgari recommended establishing a nonprofit financial intermediary, called the Qard Hassan bank. The capital for the bank would come from the monetary (cash) waqf donated by Muslims.

Cizakza (2004) also suggested a model where the cash waqf can be used to meet the social objectives of the society by providing financing assistance to the entrepreneurs through the concept of partnership (Mudharabah). He also suggested that cash waqf can be used as microfinance tools for the poor or for entrepreneurs.

Meanwhile, Lahsasna (2010) suggested the cash waqf model to enhance the financial services for SMEs in Malaysia. This suggested model is expected to improve domestic economic growth and play a vital role in the socioeconomic development by allowing the SMEs access to financial services. The investment of these cash waqf will be made with debt financing and equity financing contracts such as Murabahah, Ijarah, Istisna and Bai Bithamil Ajil, Mudharabah and Musharakah for the SMEs in Malaysia.

Also in 2010, Tohirin found that the cash waqf system was a solution to the lack of access to formal banking institutions in Indonesia. Through proper utilization and investment of these cash waqf assets, SMEs would be able to expand their business ven- tures through partnerships with the cash waqf institutions.

From these models, as proposed by the various authors, it has been shown that the integration of waqf and micro enterprises is a possibility, to effectively address the issue of financing for micro entrepreneurs. Although the model proposed by various studies has a similarity with the present study, there are also major differences as mentioned earlier. Furthermore, most of the proposed models by (Elgari 2004; Cizakza 2004; Ahmed 2007; Hassan 2010) are not validated empirically to gauge the entrepreneurs' intention to use them.

Furthermore, most of the studies discussed the conceptual and theoretical aspects of waqf and enterprise models, without any hypotheses formulated to measure the entrepreneurs' intentions to use those models. This study fills this gap by proposing an Integrated Cash Waqf Micro Enterprise Investment (ICWME-I) model which is a participatory form of contract between the waqf institutions and the micro enterprises. This model incorporates Musharakah Mutanaqisah (diminishing partnership) financing arrangements between the waqf institutions and the micro enterprises.

\section{Proposed Integrated Cash Waqf Micro Enterprise Investment (ICWME-I) ModeI}

As the existing schemes of financing are unable to meet the financial needs of micro enterprises, there is a need to look for a more effective funding scheme to help micro enterprises. An Integrated Cash Waqf Micro Enterprises Investment (ICWME-I) model is proposed with the aim of it being an alternative option to the existing micro enterprises 
Figure 2. Conceptual Framework of ICWMI-I Model

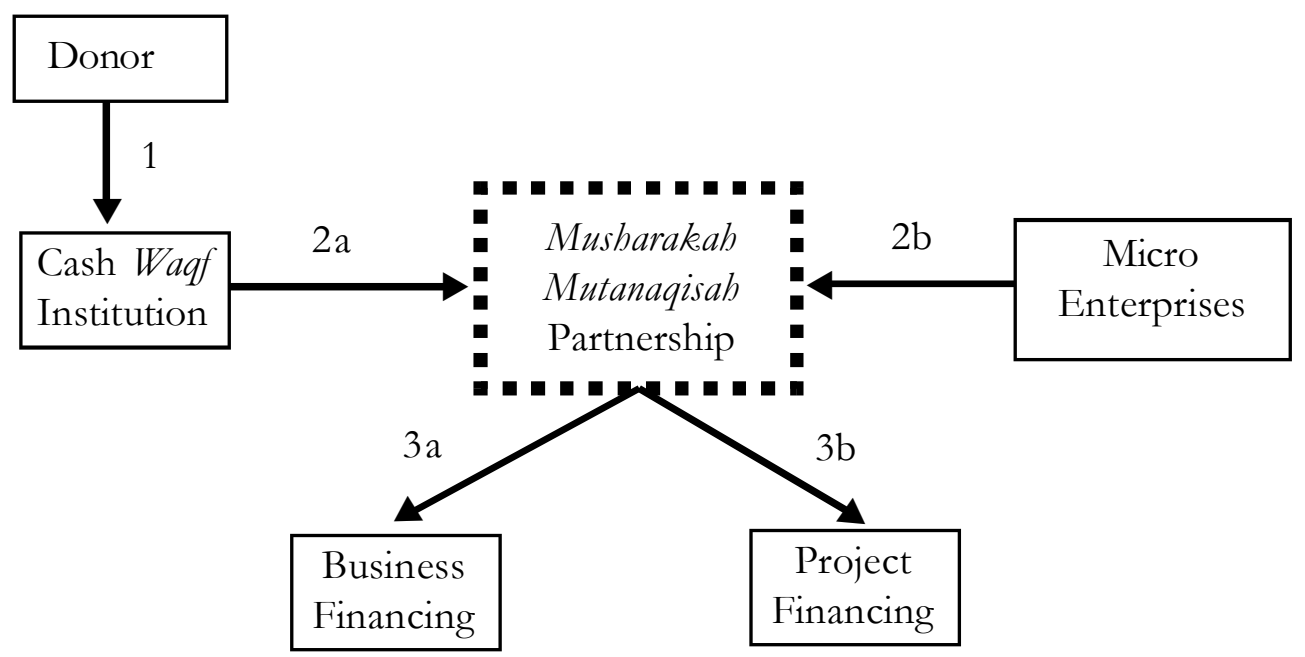

schemes for financing in Malaysia as shown in Figure 1.

Below are the detailed explanations of the above model:

- Arrow [1] indicates the flow of fund from the donors (both in the public and corporate sectors) that will contribute cash waqf to the CWI with the intention of creating perpetual waqf. The public will contribute cash waqf by voluntarily donating or purchasing waqf shares or certificates offered by the CWI. The corporate sector can contribute cash waqf as a part of their Corporate Social Responsibility (CSR) programs. The CWI becomes the mutawali (manager) of the fund. The manager would be responsible for making the necessary investment decisions for the fund. The CWI can be treated as a separate entity under the State Islamic Religious Councils (SIRCs) or the corporate sector.

- Arrow [2a] and [2b] show that the CWI will provide a financing facility by involving a Musharakah Mutanaqisah (diminishing partnership) arrangement with the mi- cro enterprises. A Musharakah Mutanaqisah (diminishing partnership) arrangement is where both the CWI and the micro enterprises jointly engage in business activities or purchase property or commercial enterprises. Later, the assets owned by the financier are divided into parts, with the understanding that the customer will gradually purchase those parts via periodic payments. The objective is for the customer to eventually become the sole owner of the property or enterprise. This arrangement is suitable for business financing [3a] and project financing [3b]. For the business financing, it can include the financing of machinery, land, electric installations, equipment, and other fixed assets. Meanwhile, the project financing involves financing of construction of shop lots and business premises.

- Under this model, the CWI requires no collateral, or needs to apply an interest rate or ask for strict documentation. However, in order to ensure this model is effectively operated, the CWI is required to conduct prior and post screening of the 
potential micro enterprises, to ensure that they are able to generate revenue, and to monitor their businesses.

After this model was developed, this study undertook an empirical survey to gauge the intentions of micro enterprises to use this model. Hence, in this study, the researcher applied the Theory of Reasoned Action (TRA) as discussed in an earlier section. This theory is basically a method to empirically test the intentions of micro entrepreneurs to use the ICWME-I model developed by the study.

\section{Methods}

\section{Data Collection}

The study focuses on micro enterprises in the Klang Valley (Selangor and Kuala Lumpur). This area was chosen, as the database for SMEs which also includes micro enterprises, showed it had the highest number. A random sampling was drawn for the survey. Sampling was conducted by distributing questionnaires to the owners of micro enterprises. The sample size was four hundred and twenty ( $\mathrm{n}=420)$ individuals. 19 (4.52 percent) of the 420 respondents were excluded due to their incomplete survey responses. This resulted in a total of 401 effective responses which were used in the data analysis procedures. Therefore, the effective return rate was 95.5 percent

\section{Sample Size}

The selection of an appropriate sample size is an important issue in Structural Equation Modeling (SEM). According to Hair et al. (2006), a sample size ranging between 200 and 400 is sufficient for SEM to give precise results. This is also supported by Kline (2011) who suggested that the sample size for SEM should be large enough ( $\mathrm{n}>200)$. Thus, by taking the suggestions of Hair et al. (2006) and Kline (2011), the present study has surveyed a total sample of 420 micro enterprises. However, only 401 effective responses were used in the data analysis procedures.

\section{Research Instruments}

This study adopted a self-administered questionnaire design. The questionnaires were adopted and adapted based on the Theory of Reasoned Action (TRA). For these TRA questionnaires, this study developed the items in the questionnaires by adapting measures which were developed by previous studies that used TRA (Ajzen \& Fishbein, 1980; Abduh, 2011; Muhammad, 2012). It was aimed at finding the acceptance and intention of micro entrepreneurs in Malaysia to use the ICWME-I model.

For example, the items included for the construct of behavioral intention are (i) "I intend to use the ICWME-I model if it is offered" coded as F38, (ii) "I plan to use the ICWME-I model if it is offered" coded as F41 and (iii) "I have a strong intention to use the ICWME-I model if it is offered" coded as F43. Meanwhile, the items included for the construct of attitude comprise (i) "Engaging with the ICWME-I model is valuable" coded as F16, (ii) "Engaging with the ICWME-I model is suitable" coded as F19 and (iii) "Engaging with the ICWME-I model is in line with my religious values" coded as F24. The items included for the construct of subjective norms include (i) "Most people who are important to me think that I should use this ICWME-I model for financing purposes" coded as F32, (ii) "Most people who are important to me think that I should use this ICWME-I model for enhancing my skills" coded as F33 and (iii) "Most people whose 
opinion I value would approve my action in using this ICWME-I model for financing purposes" coded as 34 .

\section{Data Analysis}

The collected data were analyzed using SPSS Statistics 20 and AMOS 20. Following the procedure suggested by Anderson and Gerbing (1988), a measurement model was estimated before the structural model. A Confirmatory Factor Analysis (CFA) was employed to assess the measurement model and to test the data's quality, including its reliability and construct validity checks. Structural Equation Modelling (SEM) was conducted to assess the overall fit of the proposed model and to test the hypotheses.

\section{Results and Discussions}

\section{Descriptive Analysis}

As shown in Table 1, a total of 265 (66.1 percent) of the respondents were male, while 136 (33.9 percent) were female. The respondents were classified into four age categories. The age range of the respondents consisted of 149 (37.2 percent) who were 2030 years old, 140 (34.9 percent) were $31-40$ years old, 69 (17.2 percent) were $41-50$ years old and 43 (10.7 percent) were over 50 years old. The respondents were also classified into three marital categories. Among the choices given were married, single and divorced. Most of the subjects, 268 (66.8 percent) were married. The survey also indicated that 117 (29.2 percent) of the respondents were single and 16 (4 percent) were divorced.

In terms of their education level, the respondents were classified into five categories. For this purpose, the respondents were asked to identify the highest level of education that they completed. The choices given were no education, secondary (SPM), Diploma, Bachelor degree and Master/PhD. The distribution consisted of 21 (5.2 percent) with no education, 157 (39.2 percent) had a secondary education (SPM), 115 (28.7 per-

Table 1. Descriptive Statistics for Demographic Variables of the Sample by Gender, Age, Marital Status and Education

\begin{tabular}{llcr}
\hline Items & \multicolumn{1}{c}{ Categories } & Frequency & Percent \\
\hline Gender & Male & 265 & 66.1 \\
& Female & 136 & 33.9 \\
& $20-30$ & 149 & 37.2 \\
& $31-40$ & 140 & 34.9 \\
Marital Status & $41-50$ & 69 & 17.2 \\
& $>50$ & 43 & 10.7 \\
& Single & 117 & 29.2 \\
Education & Married & 268 & 66.8 \\
& Divorced & 16 & 4 \\
& No Education & 21 & 5.2 \\
& Secondary (SPM) & 157 & 39.2 \\
& Diploma & 115 & 28.7 \\
& Degree & 83 & 20.7 \\
& Postgraduate (Master/Phd) & 25 & 6.2 \\
\hline
\end{tabular}


cent) possessed a Diploma, 83 (20.7 percent) had completed a Bachelor degree, and 25 (6.2 percent) held a postgraduate degree (Master/ $\mathrm{PhD})$.

Meanwhile, in Table 2, it shows that the respondents were categorized into 3 categories based on the number of years they were in business. 254 (63.3 percent) of the respondents had operated their business for between 0-5 years, with 101 (25.2 percent) for 6-10 years. Only 46 (11.5 percent) had more than 10 years. In terms of the category of their businesses, 387 (96.5 percent) of the respondents were in service oriented businesses, followed by 8 ( 2 percent) in agricultural ones. The remaining 4 ( 1 percent) and 2 ( 0.5 percent) were involved in manufacturing and construction, respectively.

The respondents were also classified into five groups by their annual sales turnover. The respondents were asked to pinpoint their annual sales turnover. The distribution consisted of 226 (56.4 percent) between RM10,000-RM50,000, 113 (28.2 percent) RM50,001-RM100,000, 31 (7.7 percent) RM100,001-RM150,000, 25 (6.2 percent) RM150,001-RM200,000 and 6 (1.5 percent) RM200,001-RM300,000.

Furthermore, as depicted in Table 3 below, 123 (30.7 percent) of the respondents indicated that they had applied for an external loan in the last 6 months to 1 year. Hence, it is appropriate to investigate the reasons behind their application for a loan. Table 6.4 indicates the most commonly cited reason for applying for external finance: (78) 19.5 percent of the respondents said it was for expansion, (56) 14 percent said it was for capital purchases and (41) 10.2 percent stated it was for working capital. Another reason given by (10) 2.5 percent of the respondents was that they needed the loan to finance their plans for relocating their businesses.

Table 2. Descriptive Statistics for the Demographic Variables of the Sample by the Number of Years in Business, the Category of Business and the Annual Sales Turnover

\begin{tabular}{llrr}
\hline Items & \multicolumn{1}{c}{ Categories } & Frequency & Percent \\
\hline Number of Years in Business & 0-5 Years & 254 & 63.3 \\
& 6-10 Years & 101 & 25.2 \\
& $>10$ Years & 46 & 11.5 \\
Category of Business & Services & 387 & 96.5 \\
& Agriculture & 8 & 2 \\
& Manufacturing & 4 & 1 \\
Annual Turnover & Construction & 2 & 0.5 \\
& RM10,000-RM50,000 & 226 & 56.4 \\
& RM50,001-RM100,000 & 113 & 28.2 \\
& RM100,001-150,000 & 31 & 7.7 \\
& RM150,001-RM200,000 & 25 & 6.2 \\
& RM200,001-RM300,000 & 6 & 1.5 \\
\hline
\end{tabular}


Table 3. Cross-Tabulation of Applying for a Loan and the Objectives for the Loan

\begin{tabular}{lrrrrrrrrrr}
\hline & & \multicolumn{1}{c}{ Expansion } & \multicolumn{2}{c}{$\begin{array}{c}\text { Capital } \\
\text { Purchase }\end{array}$} & \multicolumn{2}{c}{$\begin{array}{c}\text { Working } \\
\text { Capital }\end{array}$} & \multicolumn{2}{c}{ Relocation } \\
\cline { 2 - 11 } Applying for a & Frequency & No & Yes & No & Yes & No & Yes & No & Yes \\
\cline { 2 - 11 } Loan During the & No & 278 & 0 & 278 & 0 & 278 & 0 & 278 & 0 \\
Last 6 Months- 1 & Yes & 45 & 78 & 67 & 56 & 82 & 41 & 113 & 10 \\
Year & & & & & & & & & &
\end{tabular}

Table 4. Type of Problems during Loan Application

\begin{tabular}{llcrc}
\hline \multicolumn{1}{c}{ Items } & \multicolumn{1}{c}{ Categories } & Frequency & Percent \\
\hline & High Interest Rate & Yes & 296 & 73.8 \\
& & No & 105 & 26.2 \\
& StrictDocumentation Requirement & Yes & 307 & 76.6 \\
Problems During & & No & 94 & 23.4 \\
Raising External & StrictCollateral Requirement & Yes & 316 & 78.8 \\
Finance & & No & 85 & 21.2 \\
& Insufficient Amount OfFinancing & Yes & 320 & 79.8 \\
& & No & 81 & 20.2 \\
& Long Loan Durations & Yes & 326 & 81.3 \\
& & No & 75 & 18.7 \\
& Characteristics OfBusiness & Yes & 329 & 82 \\
& & No & 72 & 18 \\
\hline
\end{tabular}

Although Table 3 shows that micro enterprises may eventually succeed in raising external financing, they encounter problems in the process of obtaining their loans. Hence, the respondents were asked about the difficulties they experienced in the process of applying for and obtaining external financing during the last six months to one year.

As shown in Table 4, 73.8 percent of the respondents stated that a higher interest rate was one of the difficulties they faced in obtaining external financing. They also agreed that the strict documentation requirements and collateral requirements affected them. These two factors received 76.6 percent and 78.8 percent, respectively. A further 79.8 percent also disclosed that they were faced with the problem of insufficient amounts of financing from the financial institutions. The other obstacles, such as the long duration of their loans ( 81.3 percent) and the characteristics of their businesses (28 percent) were also seen to place undue pressure on the micro enterprises to obtain finance. 


\section{Structural Equation Modeling}

\section{Measurement Model}

A measurement model was estimated using the maximum likelihood estimation method. The initial 25 items developed for measurement were subjected to a CFA. Later, after running the new measurement models, the results of the CFA on these 23 items showed a moderate fit to the data as shown in Table 5. The chi-square value $\left(\chi^{2}\right)$ of the measurement model was $967.783(\mathrm{df}=216$, $\mathrm{p}=0.000$ ). The Normed $\chi^{2}$ value of 4.480 falls within the range of below 5 , as suggested by Marsh and Hocevar (1988). Other practical fit indices demonstrated that the measurement model fitted the data well (RMSEA 0.098; CFI 0.927). Consequently, this measurement model was used for all further analyzes.

Meanwhile, as shown in Table 6, the construct reliability values were well above the 0.70 level suggested by Nunnally (1978).
All standardized factor loadings emerged fairly high and significant, ranging from 0.622 to 0.94 . This suggested convergence of the indicators with the appropriate underlying factors (Anderson and Gerbing, 1988). The Average Variance Extracted (AVE) values for each construct were all above 0.50 (Fornell and Larcker 1981). Overall, these results showed strong evidence of the unidimensionality, reliability, and validity of the measures.

The discriminant validity of the constructs is shown in Table 7. Smith et al. (1996) proposed that each construct's AVE is compared to its Squared Correlation (SC) with other constructs. In this regard, if the average variance extracted of a factor is greater than the squared correlation between that and every other factor, the factor exhibits discriminant validity. The result shows that the square root of the AVE between each pair of factors was higher than the correlation estimated between factors, thus ratifying its discriminant validity (Hair et al. 2006).

\section{Table 5. Fit Indices for Final MM3}

\begin{tabular}{lcccccc}
\hline Model & $\chi^{2}$ & Df & Normed $\chi^{2}$ & RMSEA & CFI & Comment \\
\hline Final MM3 & 967.783 & 216 & 4.480 & 0.093 & 0.927 & The required level is achieved \\
\hline
\end{tabular}

Table 6. The CFA Results for the Measurement Model

\begin{tabular}{lccccc}
\hline Construct & Items & $\begin{array}{c}\text { Factor } \\
\text { Loading }\end{array}$ & $\begin{array}{c}\text { Cronbach Alpha } \\
\text { (Above 0.7) }\end{array}$ & $\begin{array}{c}\text { CR } \\
\text { (Above 0.6) }\end{array}$ & $\begin{array}{c}\text { AVE } \\
\text { (Above 0.5) }\end{array}$ \\
\hline Attitude & & & 0.945 & 0.937 & 0.657 \\
$($ AT) & F15 & 0.899 & & & \\
& F16 & 0.93 & & & \\
& F17 & 0.941 & & & \\
& F18 & 0.891 & & & \\
F19 & 0.866 & & & \\
& F22 & 0.622 & & & \\
& F23 & 0.659 & & & \\
& F24 & 0.574 & & & \\
& & & & & \\
\end{tabular}


Table 6. Continued

\begin{tabular}{lccccc}
\hline Construct & Items & $\begin{array}{c}\text { Factor } \\
\text { Loading }\end{array}$ & $\begin{array}{c}\text { Cronbach Alpha } \\
\text { (Above 0.7) }\end{array}$ & $\begin{array}{c}\text { CR } \\
\text { (Above 0.6) }\end{array}$ & $\begin{array}{c}\text { AVE } \\
\text { (Above 0.5) }\end{array}$ \\
\hline Subjective & & & 0.945 & 0.942 & 0.732 \\
Norm (SN) & F32 & 0.785 & & & \\
& F33 & 0.833 & & & \\
& F34 & 0.882 & & & \\
& F35 & 0.911 & & & \\
& F36 & 0.854 & & & \\
Intention & F37 & 0.862 & & & \\
(INT) & & & & \\
& F38 & 0.773 & & & \\
& F39 & 0.789 & & & \\
& F40 & 0.803 & & & \\
& F41 & 0.772 & & & \\
& F42 & 0.805 & & & \\
& F43 & 0.815 & & & \\
& F44 & 0.839 & & & \\
& F45 & 0.82 & & & \\
& F46 & 0.829 & & & \\
\hline
\end{tabular}

Table 7. Inter-construct Correlation and Squared Correlation (SC)

\begin{tabular}{lccc}
\hline Average Variance Extracted (AVE) & $\begin{array}{c}\text { INT } \\
\mathbf{( 0 . 6 4 9 )}\end{array}$ & $\begin{array}{c}\text { AT } \\
\mathbf{( 0 . 6 5 7 )}\end{array}$ & $\begin{array}{c}\text { SN } \\
\mathbf{( 0 . 7 3 2 )}\end{array}$ \\
\hline INT & 1 & & \\
ATSC & $0.585(0.342)$ & 1 & \\
SNSC & $0.6(0.36)$ & $0.569(0.323)$ & 1 \\
\hline
\end{tabular}

\section{Structural Model}

A structural model was estimated to test the hypotheses Ha1 and Ha2. The goodness-of-fit statistics of the proposed model showed that the model reasonably fits the current data. Chi-square values of the model $\left(\chi^{2}=205.109, \mathrm{df}=98, \mathrm{p}=0.000\right)$ and other goodness of fit indices (Normed $\chi^{2}=4.480$; RMSEA $=0.093$; CFI $=0.927$ ) revealed that the model fitted the data reasonably well. The structural results of the proposed model are depicted in Figure 3.

The hypothesized relationship in which micro entrepreneurs' attitudes toward their intention to use the Integrated Cash Waqf Micro Enterprise Investment (ICWME-I) model was statistically significant (â1 = 0.360 , t-value $=6.073, \mathrm{p}<0.01$ ), thus Ha1 was supported. The results indicated that when the micro entrepreneurs had a more 
Figure 3. Structural Model

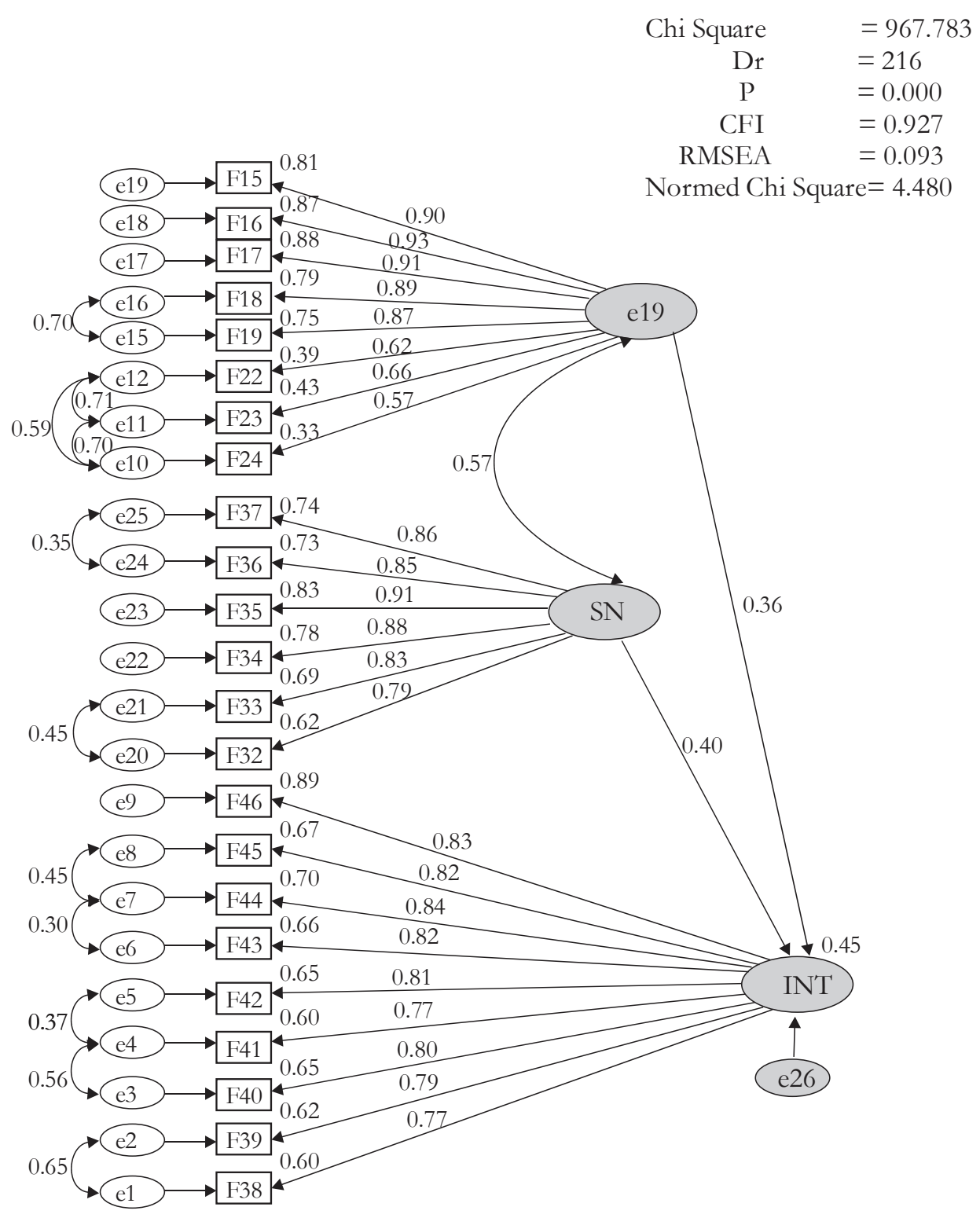

positive view about the outcome of their involvement with the ICWME-I model, the more favorable their attitude was toward their behavior and subsequently, the stronger their intention was to take the initiative to use the ICWME-I Model to finance their businesses and also for human capital development.

Meanwhile, the second hypothesis (Ha2) also found that the subjective norms had a significant influence on the micro en- trepreneurs' intention to use the ICWME-I model. Therefore, research hypothesis two was supported $(\beta 2=0.40, \mathrm{t}$-value $=7.009$, $\mathrm{p}<0.01)$ as shown in Table 8. It is believed that the social pressure groups that assert the subjective norms, including family members, relatives, friends, neighbors and co-workers, influenced the decision making process of the survey's respondents who are interested in using the ICWME-I model in the future. 
Table 8. Hypotheses Testing: The Effect of Attitude Toward Behaviour and the Subjective Norm on the Behavioral Intention of Micro Enterprises

\begin{tabular}{llcccc}
\hline & Hypothesized Path & $\begin{array}{c}\text { Standardized } \\
\text { Coefficient }\end{array}$ & t-Value & p-Value & Decision \\
\hline Ha1 & $\begin{array}{l}\text { Attitude toward behaviour } \rightarrow \\
\text { Behaviour Intention (INT) }\end{array}$ & 0.360 & $6.073^{*}$ & 0.000 & Supported \\
Ha2 & $\begin{array}{l}\text { Subjective Norm (SN) } \rightarrow \\
\text { Behaviour Intention (INT) }\end{array}$ & 0.40 & $7.009 *$ & 0.000 & Supported \\
\hline
\end{tabular}

$*_{\mathrm{p} \text {-value }}<0.01$

\section{Conclusion}

This study has examined the problems of accessing external financing faced by micro enterprises in Malaysia. The study identified financial problems as the main obstacle, due to (i) inadequate collateral, (ii) insufficient legal status, (iii) high transaction costs, (iv) insufficient information and documentation, (v) no financial track record, (vi) the nature and quality of the business, (vii) the rigidity of the financing procedure and (viii) a lack of awareness of the financial facilities.

Therefore, there is a crucial need for an alternative model of financing that should be based on being interest-free and collateralfree. In addition, this model should also be able to help micro enterprises financially. The Integrated Cash Waqf Micro Enterprises Investment (ICWME-I) model proposed integrates all these identified aspects.

This model has been tested using the Theory of Reasoned Action (TRA) in order to identify which factors are influencing the intention of the micro enterprises to use the ICWME-I model. This study has proven that both the attitude toward behavior and the subjective norms are directly significant in influencing the micro entrepreneurs' intention to use the ICWME-I model. The findings of this study can be used to develop a specific framework in which to examine other components of using the ICWME-I model's behavior and to plan appropriate intervention strategies to increase access to finance.

\section{References}

Abdullah, M. A. 2002. Industri Kecil Di Malaysia: Pembangunan Dan Masa Depan. Kuala Lumpur, Malaysia: Dewan Bahasa dan Pustaka.

Abdullah, M. A. 1999. Small And Medium Enterprises In Malaysia: Policy Issues And Challenges. Ashgate, England.

Abdullah M. A. 1999. The accessibility of the government-sponsored support programs for small and medium-sized enterprises in Penang. The International Journal of Urban Policy and Planning 16 (2): 8392. 
Abduh, M., J. Duasa, and M. Omar. 2011. Factors influence depositors' withdrawal behavior in Islamic banks: A theory of reasoned action. World Academy of Science, Engineering and Technology 60: 20742079.

Abidin, Z., K. M. Idris and F. M. Shamsudin. 2009. Predicting compliance intention on zakab on employment income in Malaysia: An application of reasoned action theory. Jurnal Pengurusan 28: 85-102

Aris N. M. 2006. SMEs: Building blocks for economic growth. Paper Presented at National Statistics Conference. Department of Statistics, Malaysia, 4-5 September.

Ajzen, I. 1991. The theory of planned behavior, organizational behavior and human. Decision Processes 50: 199-211

Cizakca, M. 2004. Cash waqf as alternative to NBFIs Bank. Paper Presented in the International Seminar On Nonbank Financial Institutions: Islamic Alternatives. Kuala Lumpur., Malaysia, March 1-3.

El-Gari, M. A. 2004. The qard Hassan Bank. Paper Presented in The International Seminar On Nonbank Financial Institutions: Islamic Alternatives. Kuala Lumpur, Malaysia, March 1-3.

Fishbein, M., and Ajzen, I. 1975. Belief, Attitude, Intention, and Behavior: An Introduction to Theory and Research. Reading, MA: Addison-Wesley

Hair, J. F., W. C. Black, B. J. Babin, R. E. Anderson, and R. L. Tatham. 2006. Multivariate Data Analysis 6. Upper Saddle River, NJ: Pearson Prentice Hall.

Hair, J. F., W. C. Black, and B. J. Babin. 2010. RE Anderson Multivariate Data Analysis: A Global Perspective. New Jersey: Pearson Education.

Hassan, N., S. T. S. Chin, J. A. Yeow, and N. A. Mohd Rom. 2010. Financial constraints and opportunities of micro enterprise entrepreneur: A theoretical framework. Paper Presented at International Conference On Business And Economics Research. Kuala Lumpur, Malaysia.

Hashim, M. K., S. A. Ahmad, and L. L. Ooi. 2008. Leadership styles and job satisfaction among employees in SMEs. In Hashim, M. K. (Ed.), Emerging Issues in Small and Medium-sized Enterprises. Sintok: Universiti Utara Malaysia Press.

Idris, F., A. A. Ab-Latif, and S. Haron. 2002. Entrepreneurs' Awareness of Bank Borrowing Offered by Government Agencies and Commercial Banks in Malaysia. ICSB

Jamak A., A. B. S. Salleh, R. S. Sivapalan, and A. Abdullah. 2011. Entrepreneurial challenges confronting micro-enterprise of Malaysian Malays. World Academy of Science, Engineering and Technology 59: 862867.

Kahf, M. 2007. The role of waqf in improving the Ummah welfare. Paper Presented at The Singapore International Waqf Conference. Singapore, March 6-7.

Kahf, M. 2003. The role of waqf in improving the Ummah welfare. Paper Presented to the International Seminar on Waqf as a Private Legal Body. Universitas Islam Sumatera Utara, Medan, Indonesia.

Lahsasna A. 2010. The role of cash-waqf in financing micro and medium-sized enterprises. Paper Presented at $7^{\text {th }}$ International Conference - The Tawhidi Epistemology: Zakat and Waqf Economy. Bangi, Selangor.

Lada, S., G. H. Tanakinjal, and H. Amin. 2009. Predicting intention to choose halal products using theory of reasoned action. International Journal of Islamic and Middle Eastern Finance and Management 2 (1): 6676.

Muhammad. 2012. Challenges of micro finance and prospect of introducing and developing IMIM in Nigeria. Unpublished PhD Thesis, International Islamic University Malaysia (IIUM) 
Mohsin M. I. A. 2008. Cash waqf a new financial product model aspects of shariah principles on ITS commercialization. Paper is presented at Islamic Banking, Accounting and Finance Conference (iBAF 2008), Faculty of Economics and Muamalat, Universiti Sains Islam Malaysia, 28-29 July 2008 at The Legend Hotel, Kuala Lumpur 2008

Ramayah T., M. N. Aizzat, M. N. Mohd Naser, and H. Hajemi. 2003. Students' choice intention of a higher learning institution: An application of the theory of reasoned action (TRA). Malaysian Management Journal 7 (1): 47-62 (2003).

Razak D. A., and M. Abduh. 2012. Customers' attitude towards diminishing partnership home financing in islamic banking. American Journal of Applied Sciences 9 (4): 593-599.

Saleh, A. S., and N. O. Ndubisi. 2006. An evaluation of SME development in Malaysia. International Review of Business Research Papers (2) (1).

Selamat, N. H., R. R. Abdul-Razak, S. A. Gapor, and Z. A. Sanusi. 2011. Survival through entrepreneurship: Determinants of successful micro-enterprises in Balik Pulau, Penang Island, Malaysia. British Journal of Arts and Social Sciences 3 (1): 23-37.

Salleh, M. M., and N. Z. M. Sidek. 2011. Rural entrepreneurship: A challenges and opportunities of rural micro enterprise (RME) in Malaysia. Interdisciplinary Journal Of Contemporary Research In Business 2 (11) (March).

Saleh, A.S., P. Caputi, and C. Harvey. 2008. Perceptions of business challenges facing Malaysian SMES: Some preliminary results. Paper presented at 5th SMEs in a Global Economy Conference, August 2nd-3rd, Senshu University, Kandajimbocho, Tokyo, Japan.

SME Masterplan (2012 - 2020). Catalysing Growth and Income. National SME Development Council.

SME Annual Report (2010/2011). Leveraging Opportunities Realizing Growth. Kuala Lumpur, Malaysia

SME Annual Report (2012/2013). Embracing Changes. Kuala Lumpur, Malaysia

Tohirin A. 2010. The Cash Waqf For Empowering The Small Businesses. Paper presented At $7^{\text {th }}$ International Conference- The Tawhidi Epistemology: Zakat And Waqf Economy, Bangi, Selangor.

Toraman C., B. Tuncsiper and S. Yilmaz. 2004. Cash Waqf in the Ottomans as Philanthropic Foundations and their Accounting Practices. Anadolu University of Turkey. 